\title{
Effect of Commercial Grade Methyl Parathion on the Survival of Pseudomonas at Varying Temperature and $\mathrm{pH}$
}

\section{${\text { Muhammadi }{ }^{*} \text {, Sadia Ishaq }}^{2}$}

${ }^{1}$ Centre for Bioresource Research, Islamabad, Pakistan.

${ }^{2}$ School of Civil and Environmental Engineering, National University of Sciences and Technology, Islamabad, Pakistan.

\section{ART I C L E I N F O}

\section{Article History}

Received: May 17, 2020

Revised: July 21, 2020

Accepted: August 19, 2020

\section{Keywords}

Methyl parathion

Pseudomonas

$\mathrm{pH}$

Pesticides
A B S T RAC T

The wide-spread use of methyl parathion as an agricultural insecticide has been causing an increased level of contamination in soil, vegetation and groundwater reservoirs and as well as adverse effects on human, flora, fauna and ecosystems. Therefore, eco-friendly and cost-effective bioremediation system are needed to remove these pollutants from the contaminated sites and mitigate its hazardous. For this purpose, a lab scale study was conducted to investigate the effect of high concentrations of commercial grade methyl parathion (50 EC) on growth of indigenous soil Pseudomonas IES-PS-1 under different environmental conditions such as $\mathrm{pH}$ and temperature. To determine the tolerance limit, Pseudomonas IES- $P s$ - 1 was grown in nutrient broth supplemented with methyl parathion $(0,200,400,600,800$, 1000 and $1200 \mathrm{mg} / \mathrm{l})$. The detailed $\mathrm{pH}(6,7,9)$ and temperature $\left(25,30\right.$ and $\left.35{ }^{\circ} \mathrm{C}\right)$ studies were conducted using higher methyl parathion ( 400 and $800 \mathrm{mg} / \mathrm{l})$. No growth was observed at 1000 and $1200 \mathrm{mg} / \mathrm{l}$ of pesticide after $96 \mathrm{hrs}$ of incubation compared to other concentrations of 200, 400, 600 and $800 \mathrm{mg} / \mathrm{l}$. The maximum growth for both 400 and $800 \mathrm{mg} / \mathrm{l}$ of pesticide was observed at $\mathrm{pH} 7$ and $30^{\circ} \mathrm{C}$. The maximum removal of total organic carbon and chemical oxygen demand for $400 \mathrm{mg} / \mathrm{lof}$ pesticide were found 50 and $52 \%$ while those for $800 \mathrm{mg} / \mathrm{l}$ were 46 and $49 \%$ respectively. Hence, this study concluded that indigenous soil bacterium Pseudomonas IES-Ps-1 could serve as an efficient candidate at $30^{\circ} \mathrm{C}$ and $\mathrm{pH} 7$ in development of a bioremediation system for the removal of toxic effects of methyl parathion like pesticides from contaminated sites.

Corresponding Author: Muhammadi

Email: muhammadi12@yahoo.com

(C) The Author(s) 2020.

\section{INTRODUCTION}

Aethyl-parathion is among the most widely used organophosphates-biased insecticide because its broad spectrum, specificity, and high efficiency toward insects and pests (Mulla et al., 2020). However, improper, continuous, and ignorant use can lead to critical environmental pollution and life-threatening health problems due to the high toxicity of methamidophos to non-target organisms (Lin et al., 2020). Therefore, methyl parathion is classified as Category Ia (extremely toxic) by the World Health Organization as Toxicity Category I (most toxic) insecticide by the United States. Environmental Protection Agency (Kumar et al., 2020). Improvement in the quality of life requires efforts to combat such pesticide wastes by identifying costeffective and nature-friendly remediation techniques. Many physicochemical methods have been developed and applied for the remediation of acephate and methamidophos, but they are thought to be too expensive to use on a large scale. For detoxification of pesticide- 
contaminated soils and water, currently, bioremediation is recognized as a cost-effective, environment-friendly technique compared to other conventional methods such as land filling, incineration, and excavation (Vidali, 2001). Biodegradation is defined as the process by which organic matter is biologically broken down under controlled conditions to an innocuous state, or to levels below concentration limits established by regulatory authorities (Mueller et al., 1996). The philosophy of the process is to enhance the rate of the natural microbial degradation of contaminants by supplementing these microorganisms with nutrients, carbon sources or electron donors. Indigenous microorganisms or enriched culture of microorganisms with specific characteristics are used in process that allows them to degrade the desired contaminant at a quicker rate. Ideally, bioremediation results in the complete mineralization of contaminants to water and carbon dioxide without the buildup of intermediates (Frazar, 2000). Worldwide, much more efforts are being made in identifying and characterizing potential microorganism for biodegradation to produce non-hazardous end products. Microbial degradation of methyl parathion has been studied extensively and its degradation pathway is well elicited (Kumar et al., 2020). Several bacterial strains are reported to utilize methyl parathion as the sole carbon and energy source. These include Flavobacterium sp. (Misra et al., 1992), Pseudomonas putida (Rani and Lalithakumari, 1994) Pseudomonas sp. A3 (Ramanathan and Lalithakumari, 1999) and Ochrobactrum sp. B2 (Qiu et al., 2007). Keeping in mind that, microbial degradation is considered to be a better and effective method to establish the bioremediation system for the contaminated sites using indigenous soil bacterium Pseudomonas IES-Ps-1. Therefore, it was aimed to determine the concentration limit of methyl parathion that support the growth of isolated microorganism under different $\mathrm{pH}$ and temperature conditions.

\section{METHODS AND MATERIAL}

\section{Chemicals used}

For growth studies, different concentrations of methyl parathion were added to nutrient broth medium to determine the utilization and biodegradation potential of IES-Ps-1. Different concentrations $(0,200,400,600$, 800, 1000 , and $1200 \mathrm{mg} / \mathrm{l}$ ) of commercial-grade methyl parathion (50 EC) were used to replicate the actual field conditions instead of selecting the analytical grade pesticide.

\section{Biodegradation test}

Seed culture of Indigenous soil bacterium Pseudomonas IES- $P s$ - 1 was prepared by growing bacterial strain in 100 $\mathrm{ml}$ nutrient broth having $150 \mathrm{mg} / \mathrm{l}$ of methyl parathion for $48 \mathrm{hrs}$ at $30{ }^{\circ} \mathrm{C}$ on an orbital shaker at $120 \mathrm{rpm}$. A loopful of culture was streaked on nutrient agar slants, incubated for $24 \mathrm{hrs}$ at $35{ }^{\circ} \mathrm{C}$. The culture slants were washed with $10 \mathrm{ml}$ of phosphate buffer having $\mathrm{pH}$ value of 7 and then used in biodegradation of methyl parathion in nutrient broth. After $24 \mathrm{hrs}$ interval, aliquots of samples were removed to determine both the microbial growth and amount of organic matter. All the experiments were performed in triplicate. Tubes without culture were maintained as control and the results are reported as average of triplicate experiments.

\section{Optical density}

The growth of Pseudomonas was determined by measuring the optical density (OD) at various time intervals such as $0,2,4,24,26,28,48,50,52,72,74,76$, 94, 96 and $98 \mathrm{hrs}$ for each concentration of pesticide at $600 \mathrm{~nm}$ using spectrophotometer (Spectronic Genesys 5).

\section{COD and TOC}

The removal of organic matter in combined medium of nutrient broth and methyl parathion was determined by measuring the total organic carbon (TOC) and biochemical oxygen demand (COD) for pesticide concentrations of 400 and $800 \mathrm{mg} \mathrm{l}-1$ as per methods described in standard methods (APHA, 2005).

\section{Experimental setup}

The growth of bacterial culture under various environmental conditions was performed in orbital shaker (Labcon Spo- MP8). In $500 \mathrm{ml}$ conical flasks, 250 $\mathrm{ml}$ of nutrient broth with different concentrations of methyl parathion $(200,400,600,800,1000$ and 1200 $\mathrm{mg} / \mathrm{l}$ ) was inoculated with $10 \mathrm{ml}$ of inoculums and incubated on orbital shaker at ambient temperature at $120 \mathrm{rpm}$. Control experiments with equal volumes of nutrient broth and pesticide but no inoculums were also conducted in parallel to determine bacterial growth.

\section{RESULTS AND DISCUSSION}

Effect of different concentrations of methyl parathion In the present study bacterial growth for six different concentrations of methyl parathion $(0,200,400,600$. 
$800,1000$ and $1200 \mathrm{mg} / \mathrm{l})$ was determined by measuring $\mathrm{OD}_{600}$. One set of experiments without addition of methyl parathion to the medium was conducted to obtain the plot of OD values indicating bacterial growth in nutrient broth alone. Among the different methyl parathion concentrations, Pseudomonas IES-Ps-1 showed a significant increase in OD for 200, 400, 600 and $800 \mathrm{mg} / \mathrm{l}$, due to increase in bacterial population. The growth curves for these four concentrations have a lag phase of $48 \mathrm{hrs}$ and a log phase of $80 \mathrm{hrs}$ which were similar to growth curve exhibited by bacteria in nutrient broth alone. For the concentration of 1000 and $1200 \mathrm{mg} / \mathrm{l}$, no significant increase in optical density was observed after $96 \mathrm{hrs}$ of incubation.
Plotting the growth curves for different methyl parathion concentrations showed that pesticide has suppressed the bacterial growth and bacteria can tolerate only a certain concentration of it. These results indicated that the bacterial culture was able to grow in presence of methyl parathion up to concentration of $800 \mathrm{mg} / \mathrm{l}$ (Figure 1). It has previously been reported that pesticides exhibited high toxicity to growth of microorganisms beyond a certain value that limits the microbial growth and subsequent degradation by microbes (Labana et al., 2005). The results obtained during these experiments are in agreement with previous studies, reporting decreased bacterial counts at high pesticide concentration (Kao et al., 2005; Yuan et al., 2000).

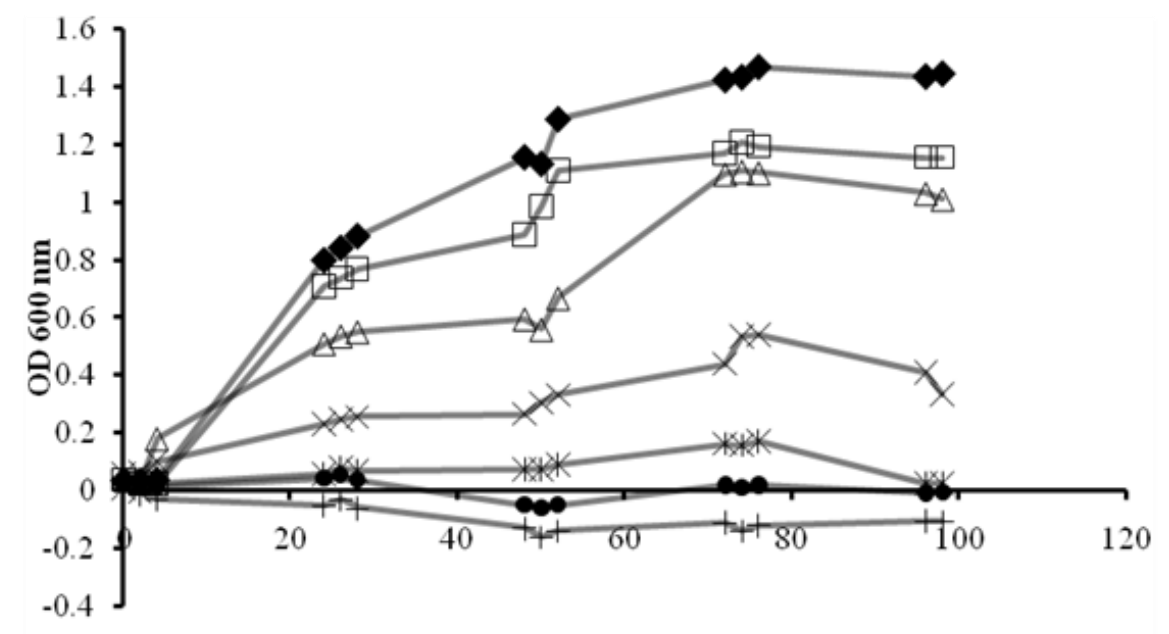

Time (hrs)

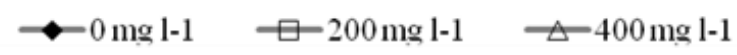

Figure 1. Growth of Pseudomonas in nutrient broth with different concentrations of methyl parathion.

\section{Effect of different temperatures}

The experiments were carried out to determine the optimal temperature for bacterial growth at $\mathrm{pH}$ 7. The results showed that bacterial growth can occur over a wide range of temperatures. However, the greatest growth of Pseudomonas IES-Ps-1 was observed at $30{ }^{\circ} \mathrm{C}$ compared to $25^{\circ} \mathrm{C}$ and $35^{\circ} \mathrm{C}$ for both 400 and $800 \mathrm{mg} / \mathrm{l}$ methyl parathion. The initial value of COD for combined media of nutrient broth and $400 \mathrm{mg} / \mathrm{l}$ of methyl parathion was $441.0 \mathrm{mg} / \mathrm{l}$ which decreased to $220.0 \mathrm{mg} / \mathrm{l}$ under the controlled temperature $\left(30{ }^{\circ} \mathrm{C}\right)$, showing a decrease (50 $\%$ ) in organic matter content. For TOC, the initial value was $180.0 \mathrm{mg} / \mathrm{l}$, which decreased to $86.0 \mathrm{mg} / \mathrm{l}$, showing a decrease of $52.0 \%$ in the organic content (Figure 2 and
3). Similarly, in the case of $800 \mathrm{mg} / \mathrm{l}$, the initial value of $\mathrm{COD}$ at $30{ }^{\circ} \mathrm{C}$ was $481.0 \mathrm{mg} / \mathrm{l}$ which decreased to 257.0 $\mathrm{mg} / \mathrm{l}$ and showed a decrease of $46.0 \%$ in COD content. For TOC, the initial value was $213.0 \mathrm{mg} / \mathrm{l}$, which decreased to $107.0 \mathrm{mg} / \mathrm{l}$ and showed a decrease of 50.0 $\%$ in TOC content (Figure 4 and 5). Although both COD and TOC do measure pesticide removal qualitatively, however a part of organic matter removal was due to pesticide degradation (Geetha et al., 2008; Krishna and Philip, 2008).

Microorganisms are poikilothermic as their temperature varies with the external environment and influence the enzyme-catalyzed reactions thereby affecting the growth. Studies show that Pseudomonas is a mesophilic microbe 
that requires a certain range of temperatures to obtain maximum growth and to perform its metabolic activities (Prescott et al., 2003). The studies of Kao et al., (2005) reported that maximum growth of $P$. mendocina and breakdown of pentachloro phenol (PCP) was achieved at $30{ }^{\circ} \mathrm{C}$. There are several similar studies which have reported the $30{ }^{\circ} \mathrm{C}$ as optimum temperature for the growth of different Pseudomonas species in the presence of different contaminants such as benzene, toluene, endosulfan, and nitrobenzene. (Arshad et al., 2008; Chang et al., 1997; Nishino and Spain, 1993).

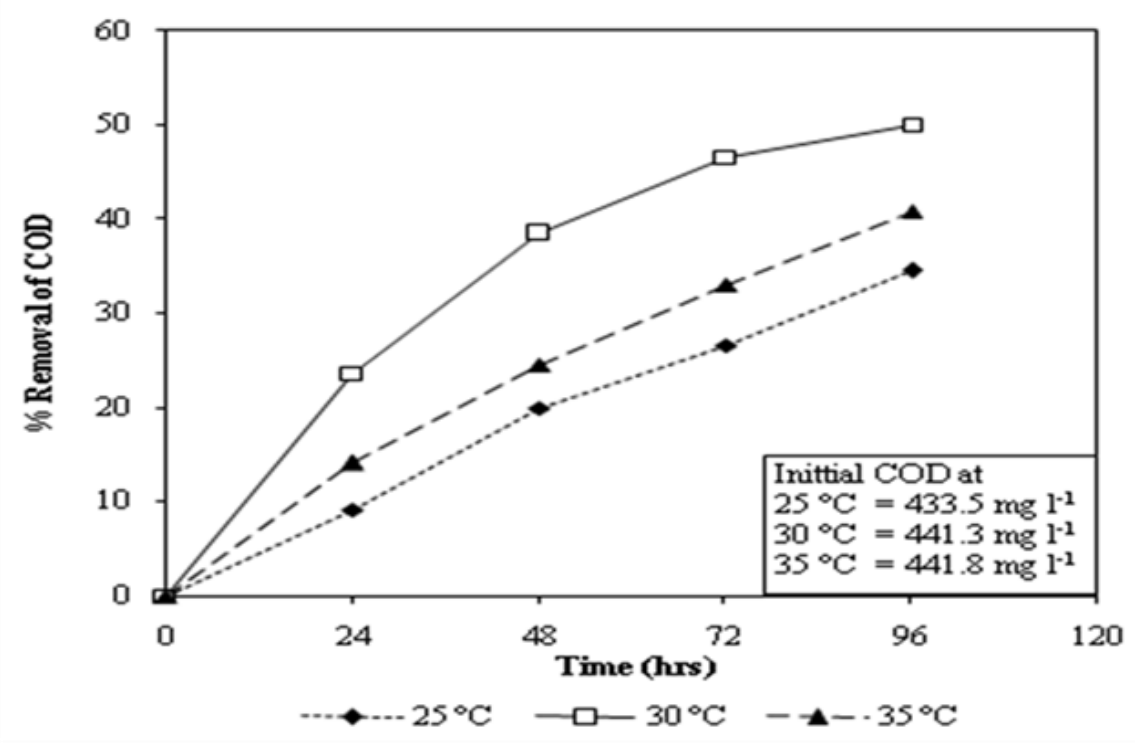

Figure 2. Effect of temperature on \% reduction of COD in $400 \mathrm{mg}-1$ methyl parathion.

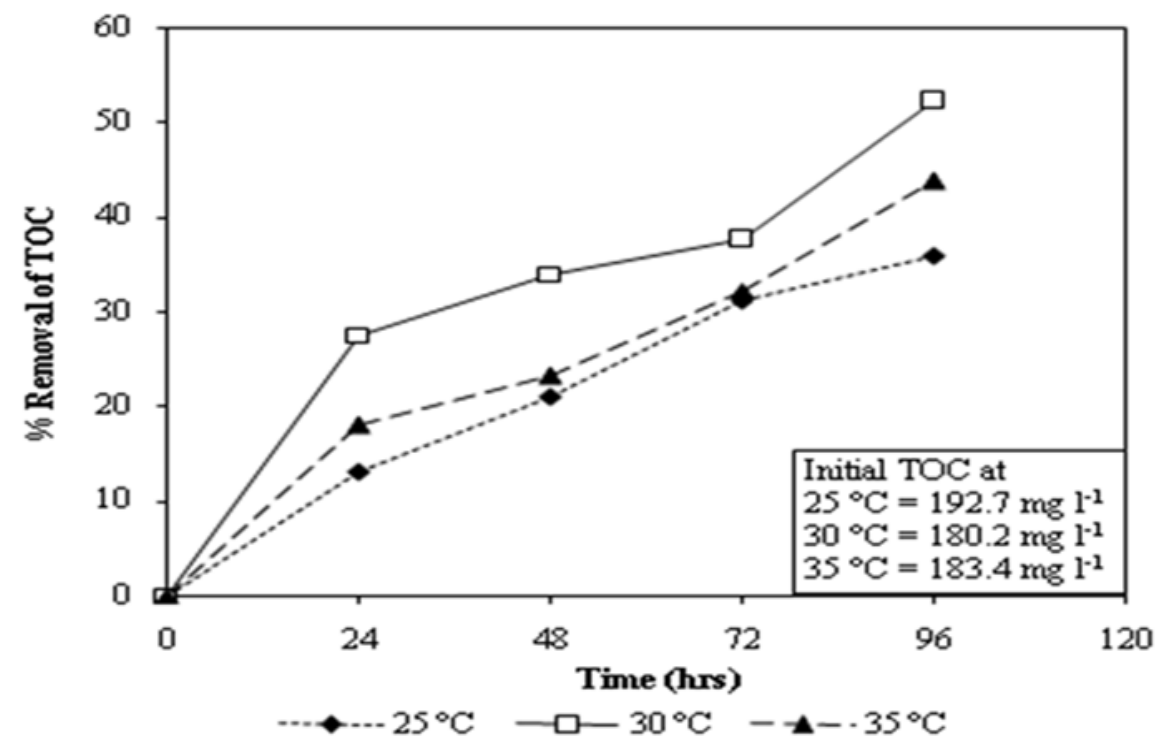

Figure 3. Effect of temperature on \% reduction of TOC in $400 \mathrm{mg}-1$ methyl parathion. 


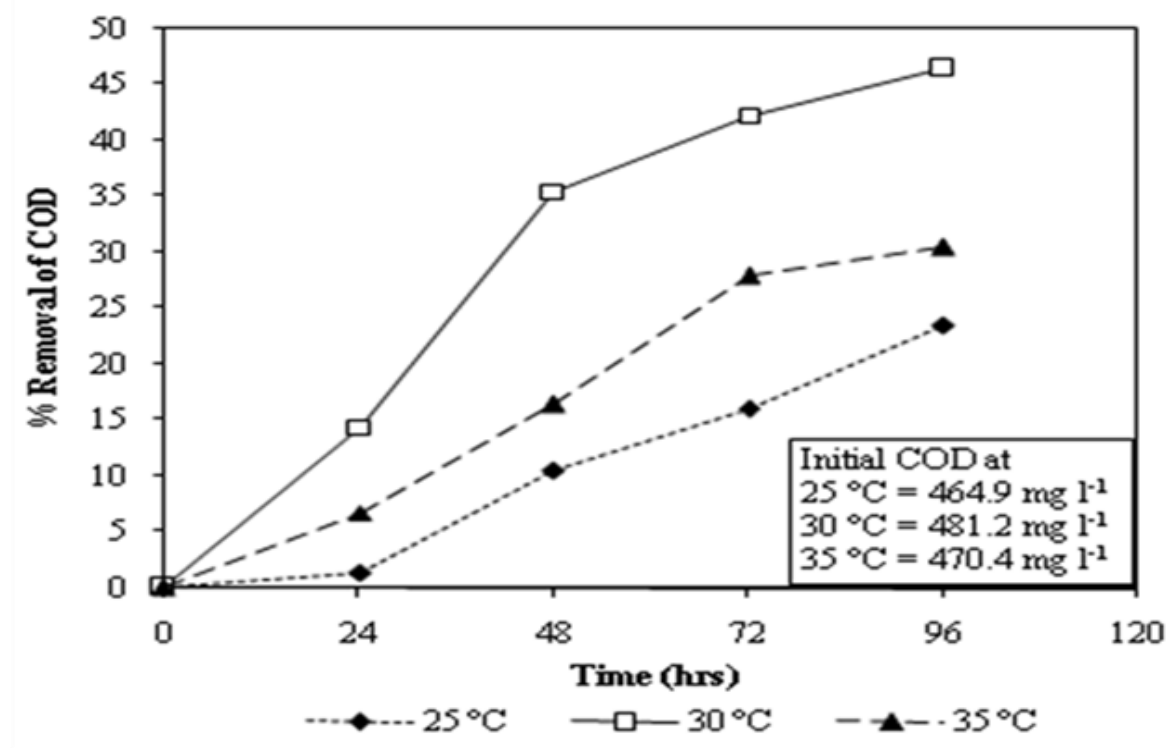

Figure 4. Effect of temperature on \% reduction of COD in $800 \mathrm{mg}-1$ methyl parathion.

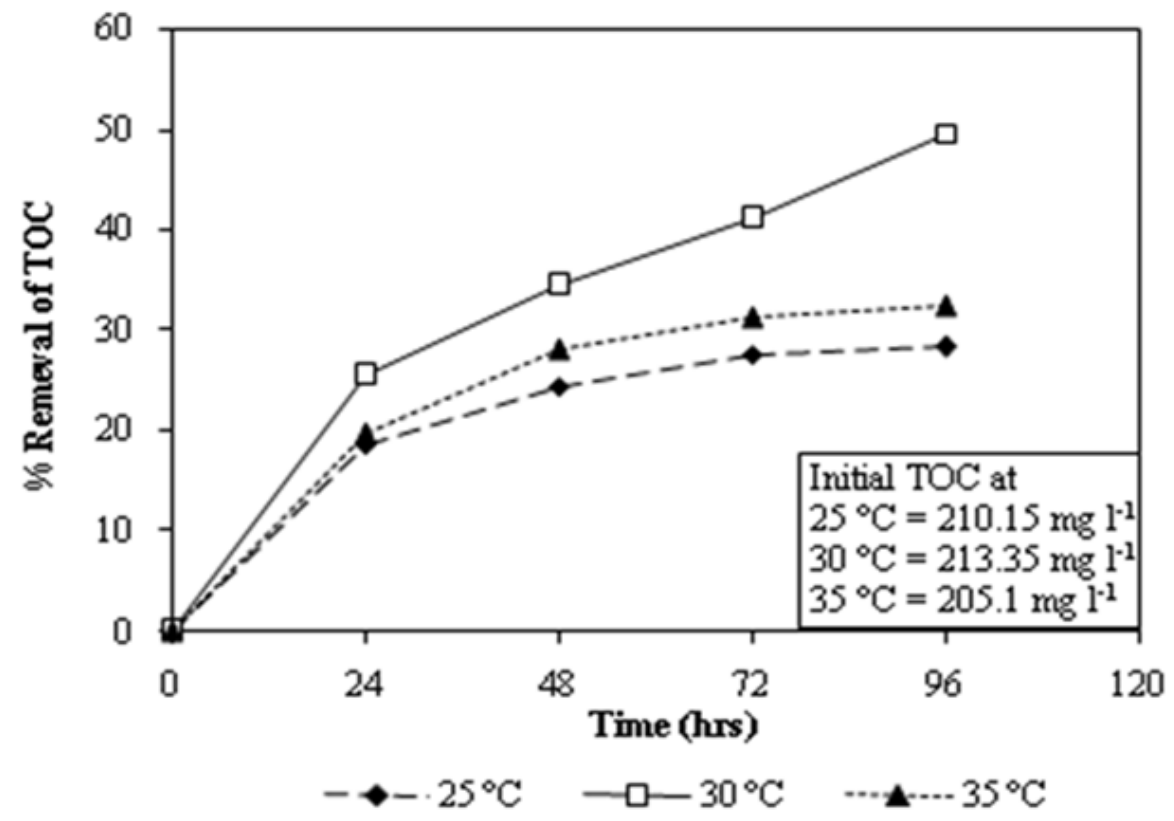

Figure 5. Effect of temperature on \% reduction of TOC in $800 \mathrm{mg}-1$ methyl parathion.

\section{Effect of different pH}

The optimum $\mathrm{pH}$ for the growth of Pseudomonas IES-Ps-1 and removal of organic matter was found neutral for both 400 and $800 \mathrm{mg} / \mathrm{l}$ methyl parathion concentrations. The initial value of COD for combined media of nutrient broth and $400 \mathrm{mg} / \mathrm{l}$ of methyl parathion was $444.0 \mathrm{mg} / \mathrm{l}$ which decreased to $234.0 \mathrm{mg} / \mathrm{l}$ under the controlled $\mathrm{pH} 7$, showing a decrease of $47 \%$ in organic matter content. For TOC, the initial value was $235.0 \mathrm{mg} / \mathrm{l}$, which decreased to $119.0 \mathrm{mg} / \mathrm{l}$, showing a decrease of $49 \%$ in the organic content (Figure 6 and 7). Similarly, in the case of 800 $\mathrm{mg} / \mathrm{l}$, the initial value of COD at $\mathrm{pH} 7$ was $490.0 \mathrm{mg} / \mathrm{l}$ which decreased to $288.0 \mathrm{mg} / \mathrm{l}$ and showed a decrease of $41 \%$ in COD content. For TOC, the initial value was 220.0 
$\mathrm{mg} / \mathrm{l}$, which decreased to $124.0 \mathrm{mg} / \mathrm{l}$ and showed a decrease of $44 \%$ in TOC content (Figure 8 and 9).

Changes in $\mathrm{pH}$ can harm microorganisms by disrupting the plasma membrane or by inhibiting the enzyme activity. Therefore, it is needed to determine $\mathrm{pH}$ preferences for achieving optimum microbial growth (Prescott et al., 2003). Results of bacterial growth and organic matter removal at varying $\mathrm{pH}$ were found inagreement with previous reports on growth of Pseudomonas in presence of 2, 4-dichlorophenol, benzene, toluene, naphthalene at $\mathrm{pH} 7$ (Elkarmi et al., 2008; Chang et al., 1992; Kao et al., 2005; Pathak et al., 2008).

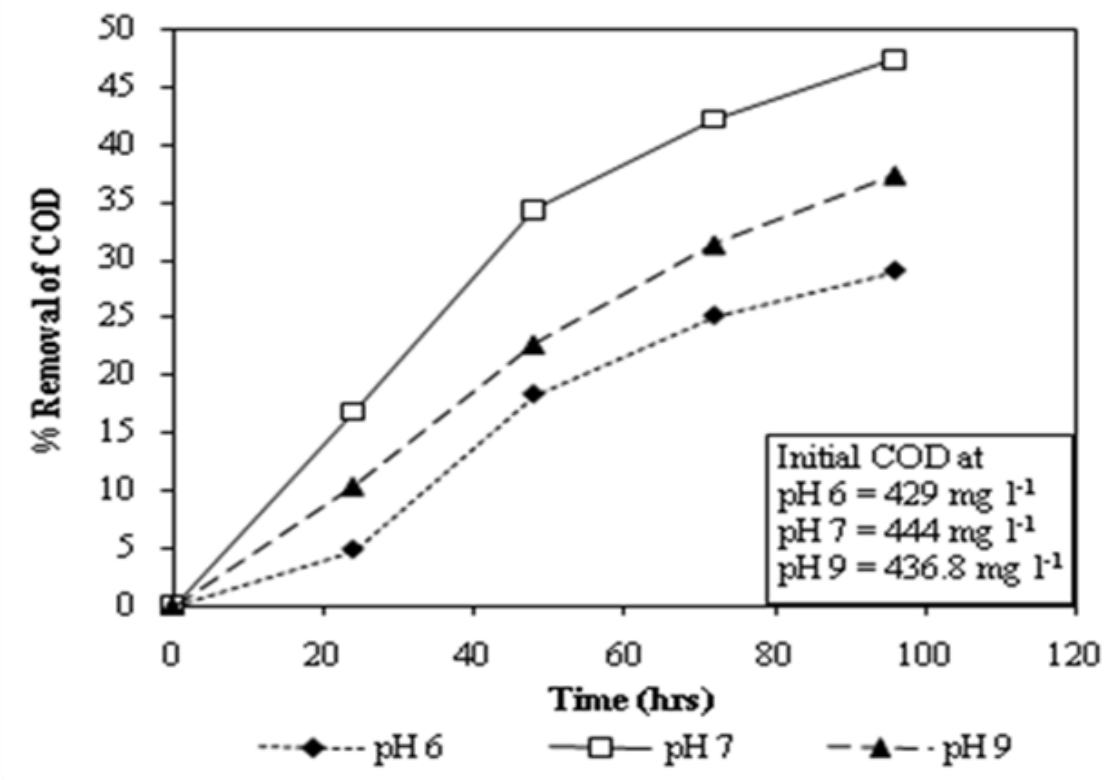

Figure 6. Effect of $\mathrm{pH}$ on \% reduction of COD in $400 \mathrm{mg}-1$ methyl parathion.

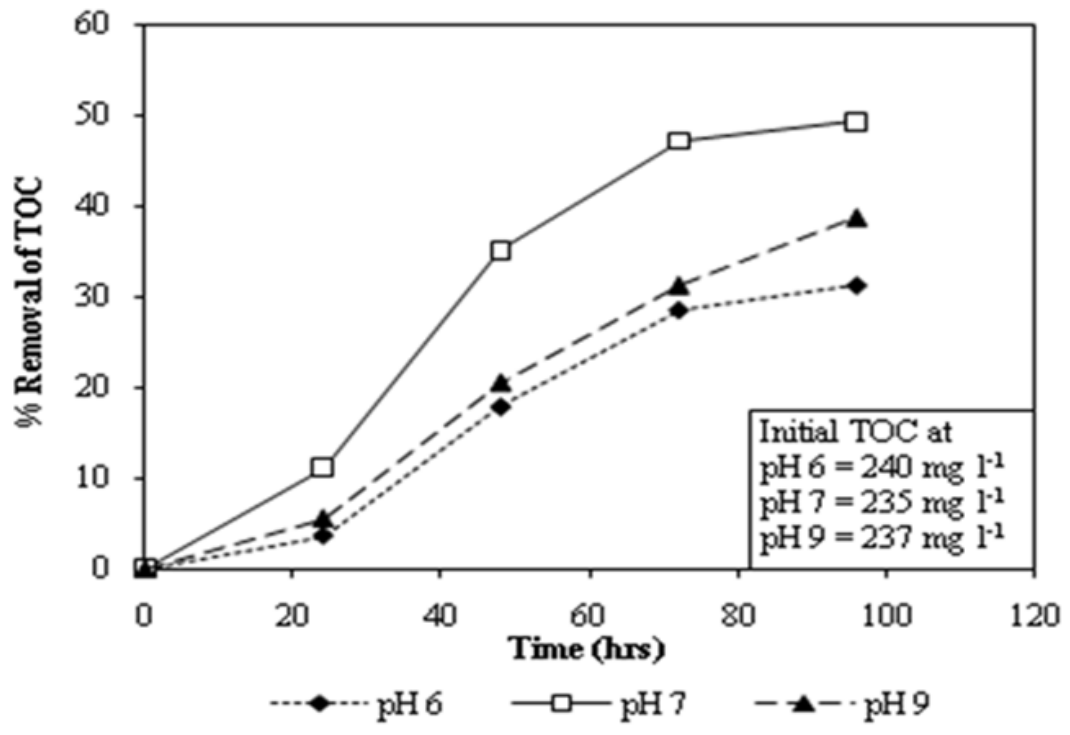

Figure 7. Effect of $\mathrm{pH}$ on $\%$ reduction of TOC in $400 \mathrm{mg}-1$ methyl parathion. 


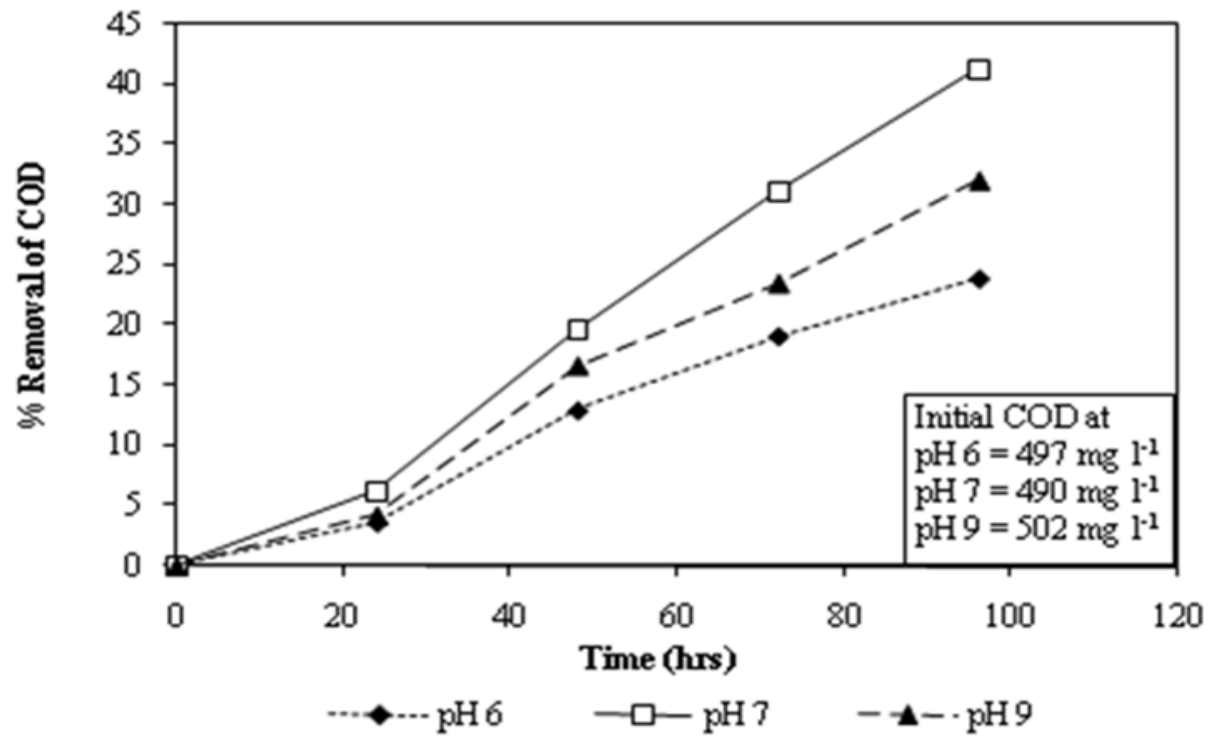

Figure 8. Effect of $\mathrm{pH}$ on \% reduction of COD in $800 \mathrm{mg}-1$ methyl parathion.

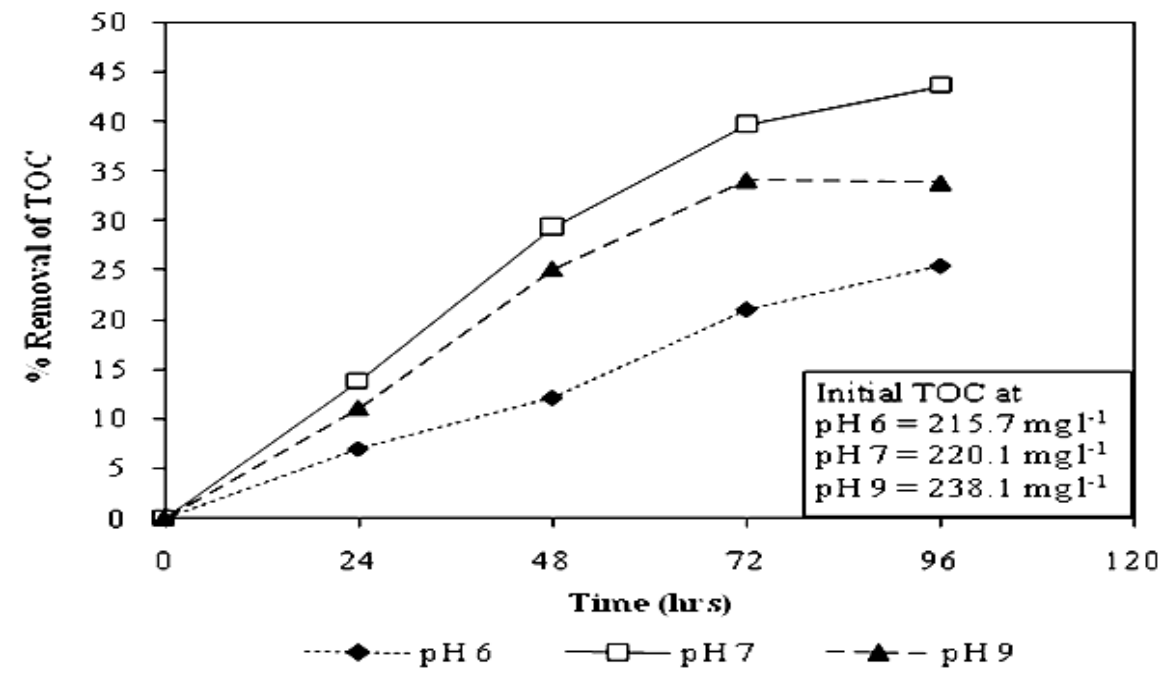

Figure 9. Effect of $\mathrm{pH}$ on $\%$ reduction of TOC in $800 \mathrm{mg}-1$ methyl parathion.

\section{CONCLUSIONS}

It was concluded that Pseudomonas IES-Ps-1 was able to grow effectively in higher concentrations of methyl parathion added to nutrient broth (up to $800 \mathrm{mg} / \mathrm{l}$ ) at 30 ${ }^{\circ} \mathrm{C}$ and $\mathrm{pH} 7$ resulted in significant removal of COD and TOC.

\section{CONFLICT OF INTEREST}

The authors declare that they have no conflicts of interest.

\section{AUTHORS CONTRIBUTIONS}

All the authors contributed equally to this work.

\section{REFERENCES}

American Public Health Association, American Water Works Association and WEF (Water Environment Federation, 2005. Standard methods for the examination of water and wastewater, twentyfirst ed. Washington DC, USA.

Arshad, M.S., M. Hussain and Saleem. 2008. Optimization of environmental parameters for biodegradation of alpha and beta endosulfan in soil slurry by Pseudomonas aeruginosa. Journal of Applied Microbiology, 104(2): 364-70.

Chang, B., B. Wen and S. Yuan. 1997. Biodegradation of benzene, toluene and other aromatic compounds 
by Pseudomonas sp. D8. Chemosphere, 35(12): 2807-2815.

Elkarmi, A., K.A. Elteen and M. Khader. 2008. Modeling the biodegradation efficiency and growth of Pseudomonas alcaligenes utilizing 2, 4dichlorophenol as a carbon source pre-and postexposure to UV radiation. Jordan Journal of Biological Sciences, 1: 7-11.

Frazar, C. 2000. The bioremediation and phytoremediation of pesticide-contaminated sites. U.S. Environmental Protection Agency. http://www.clu-in.org.

Geetha, M. and M.H. Fulekar. 2008. Bioremediation of pesticides in surface soil treatment unit using microbial consortia. African Journal of Environmental Science and Technology, 2(2): 36-45.

Kao, C.M., J.K. Liu, Y.L. Chen, C.T. Chai and S.C. Chen. 2005. Factors affecting the biodegradation of PCP by Pseudomonas mendocina NSYSU. Journal of Hazardous Materials, 124(1-3): 68-73.

Krishna, K.R. and L. Philip. 2008. Biodegradation of lindane, methyl parathion and carbofuran by various enriched bacterial isolates. Journal of Environmental Science and Health, Part B, 43(2): 157-171.

Kumar, J., A. Mishra and J.S. Melo. 2018. Biodegradation of methyl parathion and its application in biosensors. Austin Journal of Environmental Toxicology, 4(1): 1024.

Labana, S., O.V. Singh, A. Basu, G. Pandey and R.K. Jain. 2005. A microcosm study on bioremediation of $p$ nitrophenol-contaminated soil using Arthrobacter protophormiae RKJ100. Applied Microbiology and Biotechnology, 68(3): 417-424.

Lin, Z., S. Pang, W. Zhang, S. Mishra, P. Bhatt and S. Chen. 2020. Degradation of acephate and its intermediate methamidophos: mechanisms and biochemical pathways. Frontiers in Microbiology, 11: 2045.

Misra, D., S. Bhuyan, T.K. Adhya and N. Sethunathan. 1992. Accelerated degradation of methyl parathion, parathion and fenitrothion by suspensions from methyl parathion and p-nitrophenol treated soils. Soil Biology and Biochemistry, 24(10): 1035-1042.
Mueller, J.G., C.E. Cerniglia and P.H. Pritchard. 1996. Bioremediation of environments contaminated by polycyclic aromatic hydrocarbons, In: Ronald, L.C \& L. C. Don (eds.), Bioremediation: Principles and applications. Cambridge University Press, 125194.

Mulla, S.I., F. Ameen, M.P. Talwar, S.A.M.A.S. Eqani, R.N.B.G. Saxena, P.N. Tallur. 2020. "Organophosphate pesticides: impact on environment, toxicity, and their degradation, In: bioremediation of industrial waste for environmental safety. Bharagava R.N.S. Saxena (eds.), Cham: Springer, 265-290.

Nishino, S.F. and J.C. Spain. 1993. Degradation of nitrobenzene by a Pseudomonas alcaligenes. Applied and Environmental Microbiology, 59(8): 2520-2525.

Pathak, H., D. Kantharia, A. Malpani and D. Madamwar. 2009. Naphthalene degradation by Pseudomonas sp. HOB1: In-vitro studies and assessment of naphthalene degradation efficiency in simulated microcosms. Journal of Hazardous Materials, 166(2-3): 1466-1473.

Prescott, L.M., J.P. Harley and D.A. Klein. 2003. Microbiology, 5th ed. McGraw-Hill Higher Education, New York, United States.

Qiu, X., Q. Zhong, M. Li, W. Bai and B. Li. 2007. Biodegradation of p-nitrophenol by methyl parathion-degrading Ochrobactrum sp. B2. International Biodeterioration and Biodegradation, 59(4): 297-301.

Ramanathan, M.P. and D. Lailithakumari. 1999. Complete mineralization of methyl parathion by Pseudomonas sp. A3. Applied Biochemistry and Biotechnology, 80(1): 1-12.

Rani, N.L. and D. Lalithakumari. 1994. Degradation of methyl parathion by Pseudomonas putida. Canadian Journal of Microbiology, 40(12): 10001006.

Vidali, M. 2001. Bioremediation: An overview. Pure and Applied Chemistry, 73(7): 1163-1172.

Yuan, S.Y., S.H. Wei and B.V. Chang. 2000. Biodegradation of polycyclic aromatic hydrocarbons by a mixed culture. Chemosphere, 41(9): 1463-1468. 
Publisher's note: EScience Press remains neutral with regard to jurisdictional claims in published maps and institutional affiliations.

(c) (†)

Open Access This article is licensed under a Creative Commons Attribution 4.0 International License, which permits use, sharing, adaptation, distribution and reproduction in any medium or format, as long as you give appropriate credit to the original author(s) and the source, provide a link to the Creative Commons license and indicate if changes were made. The images or other third-party material in this article are included in the article's Creative Commons license, unless indicated otherwise in a credit line to the material. If material is not included in the article's Creative Commons license and your intended use is not permitted by statutory regulation or exceeds the permitted use, you will need to obtain permission directly from the copyright holder. To view a copy of this license, visit http://creativecommons.org/licenses/by/4.0/. 